\title{
Sources and ecological risk mapping of trace elements in multi-contaminated soils of gold mine employing GIS methods - Muthe Gold Mine, Iran
}

\section{Laleh Ghafouri ( $\sim$ L.Ghafouri1989@ut.ac.ir)}

University of Tehran College of Engineering https://orcid.org/0000-0002-6795-7187

Hasan Darabi

University of Tehran College of Engineering

Saeed Rahmati

University of Tehran College of Engineering

\section{Research Article}

Keywords: ecological risk assessment, heavy metal concentration, gold mine, contamination indicators, heavy metal Spatial distribution, Geographical information system (GIS)

Posted Date: October 21st, 2021

DOI: https://doi.org/10.21203/rs.3.rs-999830/v1

License: (a) (1) This work is licensed under a Creative Commons Attribution 4.0 International License. Read Full License 


\section{Abstract}

The properties of solid mine wastes are essential for understanding their potential health and ecological hazards, as well as chemical composition, although there is limited empirical data, especially in developing countries. This investigation was done to evaluate the possible trace element concentrations, sources and potential ecological risks in gold mine soil by applying Hakanson risk assessment method with ArcGIS technology. In this field study, quantitative contamination indicators like geoaccumulation index, contamination factor and ecological risk index were applied to compare three different sites. A total of 34 topsoil samples were collected from three selected areas, following which the different contamination parameters as well as sources of Arsenic, Copper Nickle, Lead and Zinc were determined. Results showed the concentration of $\mathrm{Cu}$ and As in soil samples of the gold mine area exceeded recommended standard values which seems to have a mix of anthropogenic and natural sources. The geochemical accumulation index results indicated clear signs that $\mathrm{Cu}$ with Igeo values for the three selected areas was classified as uncontaminated to moderately contaminated $(0 \leq \operatorname{lge}<1)$. In regard to $\mathrm{CF}$, the Senjedeh mine was classified as having very high contamination with $\mathrm{Cu}(\mathrm{CF} \geq 6)$. These findings indicated that the tailing dam and concentration factory were categorized as having 'low ecological risk' (RI $\leq 150)$; while Senjedeh mine was respected as having 'very high ecological risk' $(300 \leq \mathrm{Rl} 6600)$. These findings emphasize the necessity for appropriate mine wastes characterization to make management decisions point towards reducing trace element pollution of soil and the related potential environmental and human health risks.

\section{Introduction}

Trace element contamination has become one of the environmental challenges today in both developed and developing countries all over the world (Ghafouri et al. 2021; Sun et al. 2010; Zand et al. 2019). They are regarded as a dangerous sort of anthropogenic contaminants and are a major source of concern due to their wide sources, persistence, non-biodegradable properties, toxicity and accumulative behaviors (Bhuiyan et al. 2021; Huang et al. 2012; Zhu et al. 2012).

Mining is one of the most significant sources of trace elements in the environment (Chen et al. 2017; Haddaway et al. 2019). Other sources of trace elements in the environment are: dumpsite, industries, weathering, mining and mineral processing (Adewumi 2020; Fashola et al. 2016; Kormoker et al. 2019; Laniyan and Adewumi 2019; Proshad et al. 2020). Toxic trace elements related to abandoned mining territories and minerals are released into encompassing sediments, soils and dust discharging from these activities (Emmanuel et al. 2018; Laniyan and Adewumi 2020; Lilic et al. 2018).

Accumulated heavy metals in the soil around mines have triggered widespread concern because of the serious health threat they pose to people through a variety of diseases and conditions. In recent years, many scientists have investigated trace element contamination in soils around gold mines (Basu et al. 2015; Cao et al. 2015; Chen et al. 2017; Li et al. 2014; Okang'Odumo et al. 2014). 
Considering the importance of sediments and the trace elements toxicity in them, these researches have been carried out to consider the effects of trace elements on ecological systems (Guo et al. 2010; Wu et al. 2010). Most of the recently reported investigations dealing with the assessment of trace element pollution in sediments use merely the trace element content as a measure to verifying their potential effect on the environment. Nevertheless, the trace elements' total concentrations provide inadequate evidence for evaluating their toxicity or bioavailability (Sundaray et al. 2011).

When the sources of contaminants are complex and multiple, pollution zones mapping is difficult. It is also challenging to determine the pollutant's sources only using a single analytical method (Dong et al. 2019; Hu et al. 2018). From the perspective of trace element exact sources apportionment and their accumulation, the present study requires some holistic and integrated approaches. Hence, to get more reliable and precise results the ecological risk of trace elements was assessed using available tools Geoaccumulation index (Igeo), Contamination factor (CF) and potential ecological risk index (RI). These indicators are broadly used because of their capability to provide detailed evidence for chemical, and on some occasions, biological characterization of wastes such as Akoto and Anning 2021; Keshavarzi and Kumar 2019; Sulaiman et al. 2019; Tytła and Kostecki 2019. But this study applied geographic information system (GIS) for appropriate source apportionment of trace elements.

The primary goal of this research was to assess the specific sources and ecological impacts of trace elements in soils. However, the exact objectives were to (i) determine the trace elements concentration in three land-use based soils, (ii) evaluate the Geoaccumulation Index, Contamination Factor, pollution level and distribution of trace elements in soils, (iii) interpolation mapping of the ecological risk zones on the basis of observations of Arsenic, Copper, Lead, Nickle and Zinc concentrations and (iiii) providing design solutions and frameworks. The attained results from this work might reveal the overall source distribution of trace elements and ecological risk zonation in soils that would be helpful for decision-makers to articulate action-oriented contamination control measures for the industrial units, municipal and agriculture authority.

\section{Material And Methods \\ 2.1 Study area}

Muteh Gold mining area is situated $270 \mathrm{Km}$ southwest of Tehran, $45 \mathrm{Km}$ northwest of Meimeh city and $60 \mathrm{Km}$ southwest of Delijan city at the Muteh plain from Latitude $33^{\circ} 22^{\prime}$ to $33^{\circ} 49^{\prime} \mathrm{N}$ and Longitude $51^{\circ}$ $15^{\prime}$ to $59^{\circ} 28^{\prime} \mathrm{E}$ at elevation of 1983 to $2498 \mathrm{~m}$ above the sea level. Figure 1 shows the site of the study area presented by software Arc GIS ver. 10.3. The area is within the semi-arid zone with an average annual rainfall of almost $250 \mathrm{~mm}$, maximum and minimum temperatures of $27.7^{\circ} \mathrm{C}$ and $0.1^{\circ} \mathrm{C}$. At present, two of nine detected ore deposits are under operation; Senjedeh and Chah Khatoon deposits. An average of 150,000 tons of soil has been exploited every single year. With an extraction rate of 2-4 grams per ton for every day and a capacity of almost 500 tons of ore for each day, a relatively significant amount of 
materials. The yielded waste has been damped at the tailing dams. At present, the old tailing dam (with 1.7 million tons of capacity) has been filled and the existing tailing dam (1.5 million tons of capacity) is being filled. Ore extraction using cyanide solution, and smelting are located nearby to the mining sites, where dust and polluted water affect the surrounding area.

\subsection{Soil sampling and preparation}

The soil samples $(0-15 \mathrm{~cm})$ were conducted in an area of about $3 \mathrm{~km} \times 6 \mathrm{~km}$. A total of 34 samples were taken from three chosen sampling sites (tailing dam, concentration factory and Senjedeh mine). Among the samples, S1-S8 were located in the tailing dam; S9-S12 were located in the concentration factory, S13S16 were located in the Senjedeh mine and S17-S34 were located in the area between the other three selected locations. Samples density was comparatively lower in Senjedeh mine and higher in tailing dam and concentration factory due to accessibility. The samples were randomly collected, maintaining a distance of about $500 \mathrm{~m}$ from each sampling site. (Bhuiyan et al. 2021; Chaoyang et al. 2009; Zhu et al. 2012). The sampling points' location is shown in Figure 2. After air-drying and sieving via a $2 \mathrm{~mm}$ mesh sieve, soil samples were stored in polypropylene containers for ICP_OES analysis. Then About $20 \mathrm{~g}$ of soil samples were ground, and the ground materials were digested using $65 \% \mathrm{HNO}_{3}, 70 \% \mathrm{HClO}_{4}, 40 \% \mathrm{HF}$. Since all of the samples were dried in the hot box, extraction and digestion of solutions from soil were revealed using inductively coupled plasma-optical emission spectrometry (PerkinElmer ${ }^{\circledR}$ - Optima ${ }^{\mathrm{TM}} 8300$ ICP-OES) in three replicates (Afonso et al. 2019; Demarco et al. 2018; Guo et al. 2014; Langella et al. 2014; Lee et al. 2018; Nirola et al. 2015; Novo and González 2014).

\subsection{Geoaccumulation index (Igeo), contamination factor (CF)and potential ecological risk index (RI):}

The heavy metal contamination status in the study sites was assessed by quantitative contamination indicators and their respective characterization standards. These indicators included geoaccumulation index (Igeo), contamination factor (CF) and potential ecological risk index (RI). Igeo was used to determine the range of metal accumulation relative to the background level. Geoaccumulation index is classified into seven categories: Igeo $\geq 6$ extremely contaminated; $4 \leq$ Igeo $<5$ strongly to extremely contaminated; $3 \leq$ Igeo $<4$ strongly contaminated; $2 \leq$ lgeo $<3$ moderately to strongly contaminated; $1 \leq$ Igeo $<2$ moderately contaminated; $0 \leq$ Igeo $<1$ uncontaminated to moderately contaminated; Igeo $<0$ uncontaminated (Akoto and Anning 2021; Kusin et al. 2019).

$$
\text { Igeo }=\ln (\text { Sample } / 1.5 \times \text { Background })
$$

where Sample is the mean concentration of elements in the samples and Background is the preindustrial level of the same element as introduced by Hakanson (1980).

Contamination factor (CF) was used to determine the contamination level of each element using the formula as reported by Hakanson (1980) as follows: 


$$
C F=\text { Sample } / \text { Background }
$$

In which Sample is the mean concentration in sample relative to Background concentration (pre-industrial level. The CF was classified into four categories: $\mathrm{CF}<1$ low contamination; $1<\mathrm{CF}<3$ moderate contamination; $3<\mathrm{CF}<6$ considerable contamination; CF $>6$ very high contamination (Haris et al. 2017; Siddiqui and Pandey 2019)

The potential ecological risk index (RI) is introduced to evaluate the ecological risk level of heavy metals in sediments or soil by Hakanson (1980) and has become one of the most generally used diagnostic and indicator tool in research domains, such as ecology, environmental chemistry and biological toxicology (Maanan et al. 2015; Zhai et al. 2014). Rl is calculated by the following equation (Chen et al. 2020):

$$
R I=\sum_{i}^{n} E_{r}^{i}=\sum_{i}^{n}\left(T_{r}^{i} \times \frac{c_{D}^{i}}{c_{R}^{i}}\right)
$$

Where $E_{r}^{i}$ is the potential ecological risk factor of each trace element, $T_{r}^{i}$ is the toxic factor of the trace element, $C_{D}^{i}$ is the individual concentration of trace elements in the sample and $C_{R}^{i}$ is the reference value of trace elements which is the background concentration of trace elements in the sample. Based on the Hakanson approach, the $T_{r}^{i}$ for $\mathrm{Pb}, \mathrm{Cu}, \mathrm{Ni}, \mathrm{Cd}$ and $\mathrm{Zn}$ are 5, 5, 5, 30 and 1, respectively. Table 1 shows four categories of $\mathrm{RI}$ and five categories of $E_{r}^{i}$.

Table 1 Indices of potential ecological metals contamination (Kusin et al. 2019)

\begin{tabular}{|l|l|l|l|}
\hline \multicolumn{1}{|c|}{$E_{r}^{i}$} & Ecological risk & RI value & Potential ecological risk \\
\hline$E_{r}^{i}<40$ & Low risk & $\mathrm{RI}<150$ & Low risk \\
\hline $40 \leq E_{r}^{i}<80$ & Moderate risk & $150 \leq \mathrm{RI}<300$ & Moderate risk \\
\hline $80 \leq E_{r}^{i}<160$ & Considerable risk & $300 \leq \mathrm{RI}<600$ & Considerable risk \\
\hline $160 \leq E_{r}^{i}<320$ & High risk & $\mathrm{RI} \geq 600$ & Very high risk \\
\hline $320 \geq E_{r}^{i}$ & Very high risk & & \\
\hline
\end{tabular}

\subsection{Layer weighting and zoning}

Trace element contamination maps were prepared to determine different levels of risk in the study area. The layers for each element were overlaid by the Analytic Hierarchy Process (AHP). Figure 3 demonstrates the distribution of each trace element in the study area on the basis of concentration, after which the AHP was carried out to weight the map layers (Figure 4) (Kara and Doartli 2012). 


\subsection{Ecological Risk Index map}

After calculating the ecological risk index of the area, first, each point was given the value obtained from the calculation of the ecological risk index and then an interpolation tool was implemented to prepare an ecological risk map. In the end, the interpolated map was classified into 4 categories based on the given value.

\section{Statistical Analysis}

The statistical evaluations of data such as minimum, maximum, mean and standard deviation were implemented using the SPSS software package version 21.0 for windows. All maps presented in this research were generated using Geographic Information system (GIS) version 10.3.

\section{Result And Discussion}

\subsection{Spatial distribution of heavy metals:}

The metal content in soil samples is presented in Table 2 by comparing the values of the metal concentrations according to the recommended standard values of Australian Department of Environment and Conservation (2010) and Canadian Ministers of Environment (2009). The spatial distribution patterns of $\mathrm{As}, \mathrm{Cu}, \mathrm{Ni}, \mathrm{Pb}$ and $\mathrm{Zn}$ are illustrated in Fig. 3. As noted in Table 2, the mean metal concentrations in all samples were observed to be in the order of $\mathrm{Cu}>\mathrm{Zn}>\mathrm{Ni}>\mathrm{As}>\mathrm{Pb}$. The metal concentrations included $\mathrm{Ni}, \mathrm{Pb}$ and $\mathrm{Zn}$ were all within the permissible regulatory standard values except for $\mathrm{Cu}$ and As.

The range of As is between 5.32 and $20.5 \mathrm{mg} / \mathrm{kg}$ (the highest concentration in the tailing dam) giving an average of $11.16 \mathrm{mg} / \mathrm{kg}$. The As content in the soil samples of the Senjedeh mining area exceeds the recommended soil guideline values of the Canadian Ministry of Environment $(11 \mathrm{mg} / \mathrm{kg})$ and the tailing dam exceeds both the permissible guideline values of Canada $(11 \mathrm{mg} / \mathrm{kg})$ and Australia $(20 \mathrm{mg} / \mathrm{kg})$.

According to the results obtained from the As interpolation map (Fig. 3), it is observed that the concentration of arsenic in the Senjdeh mine and southeastern region of the tailings dam and factory has its highest concentration. The results clearly revealed that high concentrations of $A s$ in the southeastern region of the concentration factory came from the intensive activity and emissions of dust from the factory which is affected by wind direction. This was also consistent with the results of interpolation mapping of $\mathrm{Pb}$, which showed that the $\mathrm{As}$ and $\mathrm{Pb}$ dispersion had a very similar distribution pattern in the tailing dam and concentration factory (Fig. 3). A greater concentration of As was detected in the tailing dam compared to that of Senjedeh mine samples in the study area. It can generally agree to take that arsenopyrite mineralization in gold-bearing rocks is one of the leading factors to the increased level of As (Ahn et al. 2005; Kusin et al. 2019). 
Table 2

Descriptive statistics of different trace elements in the soil at the study area

\begin{tabular}{|c|c|c|c|c|c|}
\hline Samples & As & $\mathrm{Cu}$ & $\mathrm{Ni}$ & $\mathrm{Pb}$ & $\mathrm{Zn}$ \\
\hline 1 & 7.8 & 3695.61 & 33.31 & 9 & 147.82 \\
\hline 2 & 8 & 3588.53 & 31.58 & 10.8 & 146 \\
\hline 3 & 7.3 & 3713.67 & 37.23 & 8 & 150.15 \\
\hline 4 & 8.1 & 3764.4 & 35.1 & 6.57 & 153.4 \\
\hline 5 & 12.4 & 3641.07 & 33 & 10.26 & 143.66 \\
\hline 6 & 20.5 & 3628 & 34.7 & 12 & 145 \\
\hline 7 & 10.82 & 3701.08 & 32.3 & 6.89 & 149.16 \\
\hline 8 & 14.8 & 3721.11 & 31.61 & 9.11 & 147 \\
\hline 9 & 12.49 & 900 & 7 & 5 & 45.03 \\
\hline 10 & 12.1 & 956.4 & 6.52 & 4.5 & 43 \\
\hline 11 & 12.35 & 886.23 & 7.5 & 5.5 & 47.09 \\
\hline 12 & 13.18 & 934.71 & 7.88 & 6.6 & 38.04 \\
\hline 13 & 11.9 & 895.11 & 6.83 & 4.2 & 51.6 \\
\hline 14 & 12.52 & 922.78 & 5 & 5.22 & 51.38 \\
\hline 15 & 12.83 & 890.54 & 9.1 & 6.34 & 39.33 \\
\hline 16 & 11.59 & 878.47 & 10.5 & 3.37 & 42 \\
\hline 17 & 12.81 & 915.15 & 4.51 & 3.5 & 48.09 \\
\hline 18 & 12.69 & 940.34 & 6.8 & 6.51 & 45.07 \\
\hline 19 & 12.64 & 887.36 & 8.2 & 4.98 & 40.75 \\
\hline 20 & 12.22 & 927.08 & 5.8 & 5.58 & 48.1 \\
\hline 21 & 12.65 & 893.6 & 12.53 & 4.5 & 49.78 \\
\hline 22 & 12.9 & 918.18 & 3.91 & 4.34 & 39.33 \\
\hline 23 & 12.16 & 955.98 & 6.16 & 6.5 & 44.8 \\
\hline 24 & 13.13 & 844 & 7.92 & 4.72 & 46.91 \\
\hline 25 & 11.17 & 3300.47 & 29.15 & 8.5 & 140 \\
\hline 26 & 8.44 & 3246.5 & 27.6 & 8.1 & 142.6 \\
\hline Loading [MathJax]/jax/output/CommonHTML/fonts/TeX/fontdata.js & 8.67 & 3000.55 & 25.32 & 7.81 & 132.33 \\
\hline
\end{tabular}




\begin{tabular}{|llllll|}
\hline Samples & As & $\mathbf{C u}$ & $\mathbf{N i}$ & $\mathbf{P b}$ & $\mathbf{Z n}$ \\
\hline 28 & 5.32 & 3165.76 & 26.33 & 8.5 & 127.15 \\
\hline 29 & 11.38 & 3468.56 & 6.51 & 8.72 & 116.01 \\
\hline 30 & 7.26 & 3125.08 & 34.3 & 7.53 & 140.07 \\
\hline 31 & 12.5 & 3503.84 & 35.1 & 9.5 & 153.63 \\
\hline 32 & 8.22 & 3318.07 & 36.75 & 10.52 & 139.94 \\
\hline 33 & 5.86 & 3325.76 & 24.22 & 6.58 & 132.08 \\
\hline 34 & 10.9 & 3425 & 26.83 & 7.45 & 134.7 \\
\hline Standard deviation & 2.91 & 1304.97 & 12.70 & 2.22 & 49.28 \\
\hline Min & 5.32 & 844 & 3.91 & 3.37 & 38.04 \\
\hline Max & 20.5 & 3764.4 & 37.23 & 12 & 153.63 \\
\hline Mean & 11.16 & 2261.14 & 19.32 & 6.97 & 95.91 \\
\hline Reference values (mg/kg) & & & & & \\
\hline Canadian Ministry of Environment (2009) & 11 & 63 & 37 & 45 & 290 \\
\hline $\begin{array}{l}\text { Australian Dep. Of Environment and Conservation } \\
\text { (2010) }\end{array}$ & 20 & 100 & 60 & 600 & 200 \\
\hline Pre-industrial level & & & & & \\
\hline a Hakanson (1980). & 15 & 50 & 80 & 70 & 175 \\
\hline
\end{tabular}

The range of $\mathrm{Cu}$ in this study was observed between 844 (tailing dam) and $3764.4 \mathrm{mg} / \mathrm{kg}$ (Senjedeh mine) with an average of $2261.14 \mathrm{mg} / \mathrm{kg}$. The concentration of Cu element in all of the three sampling areas exceeded the permissible limits of the Canadian Ministry of Environment $(63 \mathrm{mg} / \mathrm{kg})$ and Australian Department of Environment and Conservation $(100 \mathrm{mg} / \mathrm{kg})$. The fact that the highest concentration of Cu was observed in the Senjedeh mining area because the mining area is the parent materials of soils. The findings in the current work are also consistent with those derived by Bhuiyan et al. (2021), who revealed that As indicated natural weathering from parent materials and its concentration varied significantly with land use changes.

The mean soil concentrations of $\mathrm{Ni}, \mathrm{Pb}$ and $\mathrm{Zn}(19.3,6.97,95.91 \mathrm{mg} / \mathrm{kg})$ were below the recommended limits set by presented reference values, with the tailing dam being the most contaminated (with $\mathrm{Ni}, \mathrm{Pb}$ and $\mathrm{Zn}$ ). Notably, $\mathrm{Ni}$ and $\mathrm{Zn}$ were also observed to have a similar distribution pattern in the tailing dam and concentration factory which might largely derive from $\mathrm{Ni}$ and $\mathrm{Zn}$ in the smoke discharged from smelters, like the cases of $\mathrm{Pb}$ and $\mathrm{As}$. 
Figure 4 indicates overlaid map layers using the Analytic Hierarchy Process (AHP). Concentrations of the five metal elements in three sampling sites indicated significant variations which are mainly due to the spatial differences such as functional properties of concentration factory, tailing dam and mining activities. According to the results obtained from overlaying, as expected, the tailings dam and concentration factory have more pollutants than other places. As the distance from these areas increases, the concentration of elements and the level of pollutants decrease. The only exception in the area is the Cu concentration in the Senjadeh mine area, which is extremely high. Also, compared to the standard concentration of elements in the soil, none of the studied elements, except $\mathrm{Cu}$, have a toxic concentration, only the tailing dam and factory have a higher concentration of elements than other areas which is not toxic.

This is consistent with the result obtained by Chaoyang et al. (2009), who discovered that the heavy metals concentration in Shuikoushan is the result of volatile particulates of the chimneys, airborne emissions of aerosols, leaching and chemical weathering of tailings and level off with distance from the source of pollution. Due to the possibility of spreading pollutants to pristine pastures adjacent to creating a buffer zone at the edge of the tailings dam is recommended. On the other hand, because one of the ways of spreading these pollutants is the prevailing seasonal winds, so the construction of windbreak trees suitable for the region also seems appropriate.

In the tailings dam, due to the bare soil and the release of contaminants by wind and water erosion, it is recommended to plant accumulator and stabilizer species that are resistant to harsh environmental conditions. It is also suggested to cultivate species with significant aerial parts and root systems to create porosity in the soil for absorbing runoff caused by cross-sectional rainfall.

\subsection{Geo-accumulation index and contamination factor}

Geochemical indices of the research area including contamination factor and geo-accumulation index (Igeo) are presented in Table 3. Igeo was calculated to evaluate the accumulation status of many toxic metals in various sediments and soils (Mushtaha et al. 2017). The presence of metals in the soil of the tailing dam, Senjedeh mine and around the concentration factory such as $\mathrm{As}, \mathrm{Cu}, \mathrm{Ni}, \mathrm{Pb}$ and $\mathrm{Zn}$ had been assessed for their Igeo. All samples were observed to be uncontaminated except for Cu. All the metals except for $\mathrm{Cu}$ have geo-accumulation index values below 0 , demonstrating that the samples were uncontaminated. However, concerning $\mathrm{Cu}$, the Igeo values for the tailing dam, Senjedeh Mine and the concentration factory were classified as uncontaminated to moderately contaminated $(0 \leq \operatorname{lgeo<1)}$.

In regard to $\mathrm{CF}$, it was noticed that all samples were considered as having low contamination of all the metals $\mathrm{Ni}, \mathrm{Pb}$ and $\mathrm{Zn}$ except for As and $\mathrm{Cu}$. Tailing dam and concentration factory are categorized as having moderate contamination of As with CFs 1.153 and 1.313 and Cu with CFs 1.76 and 1.92, respectively $(1 \leq \mathrm{CF}<3)$; Senjedeh mine was classified as having very high contamination with $\mathrm{Cu}$ (CF $\geq 6$ ). As a result, the geochemical indices have revealed a generally low level of contamination with all the presented metals, except for Cu. This is in line with the earlier discussion that most of the presented 
metals in the samples were in concentrations less than the permissible regulatory guidelines, however, that of $\mathrm{Cu}$ has surpassed most of the suggested guideline values.

Table 3

Geo-accumulation (Igeo), contamination factor (CF) of each trace element in observed sites

\begin{tabular}{|lllllll|}
\hline Geochemical indices & location & As & $\mathbf{C u}$ & $\mathbf{N i}$ & $\mathrm{Pb}$ & $\mathrm{Zn}$ \\
\hline Igeo & Factory & -0.057 & 0.107 & -0.499 & -0.313 & -0.817 \\
\cline { 2 - 7 } & Tailing dam & -0.114 & 0.069 & -0.560 & -1.066 & -0.446 \\
\cline { 2 - 7 } CF & Senjedeh mine & -0.221 & 0.802 & -0.756 & -1.243 & -0.648 \\
& Factory & 1.313 & 1.92 & 0.475 & 0.728 & 0.228 \\
\cline { 2 - 7 } & Tailing dam & 1.153 & 1.76 & 0.412 & 0.128 & 0.537 \\
\hline Senjedeh mine & 0.9 & 9.52 & 0.262 & 0.085 & 0.337 \\
\hline
\end{tabular}

\subsection{Ecological risk assessment}

The metals' presence in the concentration factory, tailing dam and Senjedeh mine such as $\mathrm{As}, \mathrm{Cu}, \mathrm{Ni}, \mathrm{Pb}$ and $\mathrm{Zn}$ were assessed for their potential ecological risk. Table 4 reveals the contributions of each element $\left(E_{r}^{i}\right)$ to the potential ecological risk index (RI). Regardless of the types of samples, compared to other heavy metals in the samples, the contribution of $\mathrm{Cu}$ to the total RI was noticeable. The results revealed that all samples were dominated by $\mathrm{Cu}$, particularly in the Senjedeh mine. The value of RI was the highest for the Senjedeh mine (380.94) and was the lowest in soils of the concentration factory (24.65). The $E_{r}^{i}$ values for $\mathrm{Cu}$, based on the risk index classification of metals introduced by Hakanson (1980), were considered as; considerable potential ecological risk for tailing dam $\left(80 \leq E_{r}^{i}<160\right)$ and very high ecological risk for Senjedeh mine $\left(E_{r}^{i}>320\right)$. For RI, tailing dam and concentration factory were categorized as having 'low ecological risk' (RI $\leq 150)$; while Senjedeh mine was respected as having 'very high ecological risk' $(300 \leq \mathrm{Rl}<600)$. Notably, the influence of $\mathrm{Cu}$ on the total RI was very apparent, recommending the appropriate control treatment for studied metal elements in the mining area.

Table 4

ecological risk index (RI)

\begin{tabular}{|c|c|c|c|c|c|c|c|}
\hline \multirow[t]{2}{*}{ Location } & \multicolumn{5}{|c|}{$E_{r}^{i}(\mathrm{ppm})$} & \multirow[t]{2}{*}{ RI } & \multirow[t]{2}{*}{ Contamination degree } \\
\hline & As & $\mathrm{Cu}$ & $\mathrm{Ni}$ & $\mathrm{Pb}$ & $\mathrm{Zn}$ & & \\
\hline Tailing dam & 5.75 & 91.5 & 0.7 & 0.9 & 0.225 & 99.075 & Considerable risk \\
\hline Factory & 9.85 & 9.6 & 3.8 & 1.2 & 0.2 & 24.65 & Low risk \\
\hline Senjede Mine & 6.3 & 369.6 & 3.4 & 0.9 & 0.74 & 380.94 & Very high risk \\
\hline
\end{tabular}


Figure 5 illustrates the interpolation mapping of the potential ecological risk index in the sampled areas. According to the results, it seems that the Senjedeh mine with a risk index of 380.94 has the highest probability of risk in the region. While comparing the results of the analysis with the standard limit of elements in the soil, all elements in the region except $\mathrm{Cu}$ have low pollution. Therefore, it can be concluded that the $\mathrm{Cu}$ in this region is the only hazardous pollutant that caused to high ecological risk index of the Senjedeh mine.

\section{Conclusion}

Abandoned mine waste contains certain amounts of potentially hazardous elements for the environment. Human interventions in the mining area and neighboring areas have severely affected the landscape and natural environment. This study was carried out to evaluate the possible trace element concentrations, sources and potential ecological risks in Muthe gold mine soil. About one-sixth of the study area is affected by mine tailings, with effects such as changes in land surface topography, immature infertile soil, and poor grass and shrub structure. Findings show that human impact related to mining activities is evident in the studied soils. Gold mining activities of the Muthe mining area have caused the study area to become seriously polluted with trace elements. This was especially true for As and Cu which their observed concentrations were higher than the recommended standard values. The geochemical accumulation index showed serious Cu contamination ( $0 \leq$ lgeo $<1$ ), arsenic (with CFs 1.153 and 1.313 for both tailing dam and concentration factory) and to some extent zinc and nickel with a clear dispersion. The overall pollution degrees of trace elements are in the order of $\mathrm{Cu}>\mathrm{As}>\mathrm{Zn}>\mathrm{Ni}>\mathrm{Pb}$. Sources of trace elements in the studied area are mostly mining, mineral processes (chimneys, airborne emissions of aerosols, leaching and chemical weathering of tailings) and other sources such as natural sources (parent materials of soils) also influence their accumulation in the environment. It is recommended to create a buffer zone at the edge of the tailing dam to prevent pollutants spread to pristine pastures adjacent, construction of windbreak trees to reduce contaminant release by wind and water and planting accumulator and stabilizer species that are resistant to harsh environmental conditions. It is also suggested to cultivate species with significant aerial parts and root systems to create porosity in the soil for absorbing runoff caused by cross-sectional rainfall.

\section{Declarations}

Funding No funding was received for conducting this study.

Financial interests The authors declare they have no financial interests.

Conflicts of interest Authors have no conflict of interest to declare that are relevant to the content of this article.

Availability of data and material All data analysed during this study are included in this manuscript. 
Ethics approval Not applicable.

Consent to participate Not applicable.

Consent for publication Not applicable.

\section{References}

Adewumi, A. J. (2020). Contamination, sources and risk assessments of metals in media from Anka artisanal gold mining area, Northwest Nigeria. Sci. Total.

Environ. 718: 137235. https://doi.org/10.1016/j.scitotenv.2020.137235.

Afonso, T. F., Demarco, C. F., Pieniz, S., Camargo, F. A., Quadro, M. S., \& Andreazza, R. (2019). Potential of Solanum viarum Dunal in use for phytoremediation of heavy metals to mining areas, southern Brazil. Environ. Sci. Pollut. Res. 26(23): 24132-24142. https://doi.org/10.1007/s11356-019-05460-z.

Ahn, J. S., Park, Y. S., Kim, J. Y., \& Kim, K. W. (2005). Mineralogical and geochemical characterization of arsenic in an abandoned mine tailings of Korea. Environ. Geochem. Health 27(2): 147-157. https://doi.org /10.1007/s10653-005-0121-8.

Akoto, R., \& Anning, A. K. (2021). Heavy metal enrichment and potential ecological risks from different solid mine wastes at a mine site in Ghana. Environ. Adv. 3:

100028. https://doi.org/10.1016/j.envadv.2020.100028.

Basu, N., Clarke, E., Green, A., Calys-Tagoe, B., Chan, L., Dzodzomenyo, M., ... \& Wilson, M. L. (2015). Integrated assessment of artisanal and small-scale gold mining in Ghana-Part 1: Human health review. Int. j. Environ. Res. Public Health 12(5): 5143-5176. https://doi.org/10.3390/ijerph120505143.

Bhuiyan, M. A. H., Karmaker, S. C., Bodrud-Doza, M., Rakib, M. A., \& Saha, B. B. (2021). Enrichment, sources and ecological risk mapping of heavy metals in agricultural soils of dhaka district employing SOM, PMF and GIS methods. Chemosphere 263:

128339. https://doi.org/10.1016/j.chemosphere.2020.128339.

Cao, F., Kong, L., Yang, L., \& Zhang, W. (2015). Geochemical fractions and risk assessment of trace elements in soils around Jiaojia gold mine in Shandong Province, China. Environ. Sci. Pollut. Res. 22(17): 13496-13505. https://doi.org/10.1007/s11356-015-4618-0.

Chaoyang, W. E. I., Cheng, W. A. N. G., \& Linsheng, Y. A. N. G. (2009). Characterizing spatial distribution and sources of heavy metals in the soils from mining-smelting activities in Shuikoushan, Hunan Province, China. J. Environ. Sci. 21(9): 1230-1236. https://doi.org/10.1016/S1001-0742(08)62409-2.

Chen, J., Zhang, H., Li, J., Liu, Y., Shi, W., \& Hu, H. (2020). The toxic factor of copper should be adjusted during the ecological risk assessment for soil bacterial community. Ecol. Indic. 111: 
Chen, M., Lu, W., Hou, Z., Zhang, Y., Jiang, X., \& Wu, J. (2017). Heavy metal pollution in soil associated with a large-scale cyanidation gold mining region in southeast of Jilin, China. Environ. Sci. Pollut. Res. 24(3): 3084-3096. https://doi.org/10.1007/s11356-016-7968-3.

Demarco, C. F., Afonso, T. F., Pieniz, S., Quadro, M. S., Camargo, F. A., \& Andreazza, R. (2018). In situ phytoremediation characterization of heavy metals promoted by Hydrocotyle ranunculoides at Santa Bárbara stream, an anthropogenic polluted site in southern of Brazil. Environ. Sci. Pollut. Res. 25(28): 28312-28321. https://doi.org/10.1007/s11356-018-2836-y.

Dong, B., Zhang, R., Gan, Y., Cai, L., Freidenreich, A., Wang, K., ... \& Wang, H. (2019). Multiple methods for the identification of heavy metal sources in cropland soils from a resource-based region. Sci. Total. Environ. 651: 3127-3138. https://doi.org/10.1016/j.scitotenv.2018.10.130.

Emmanuel, A. Y., Jerry, C. S., \& Dzigbodi, D. A. (2018). Review of environmental and health impacts of mining in Ghana. J. Health Pollut. 8(17): 43-52. https://doi.org/10.5696/2156-9614-8.17.43.

Fashola, M. O., Ngole-Jeme, V. M., \& Babalola, O. O. (2016). Heavy metal pollution from gold mines: environmental effects and bacterial strategies for resistance. Int. j. Environ. Res. Public Health 13(11): 1047. https://doi.org/10.3390/ijerph13111047.

Ghafouri, L., Daryabeigi-Zand, A., \& Mohammadi, M. (2021). Phytoextraction potential of halophyte plants under industrial multi-metal contaminated sites. Acta Ecologica

Sinica. https://doi.org/10.1016/j.chnaes.2021.03.005.

Guo, P., Wang, T., Liu, Y., Xia, Y., Wang, G., Shen, Z., \& Chen, Y. (2014). Phytostabilization potential of evening primrose (Oenothera glazioviana) for copper-contaminated sites. Environ. Sci. Pollut. Res. 21(1): 631-640. https://doi.org/10.1007/s11356-013-1899-z.

Guo, W., Liu, X., Liu, Z., \& Li, G. (2010). Pollution and potential ecological risk evaluation of heavy metals in the sediments around Dongjiang Harbor, Tianjin. Procedia Environment. Sci. 2: 729-

736. https://doi.org/10.1016/j.proenv.2010.10.084.

Haddaway, N. R., Cooke, S. J., Lesser, P., Macura, B., Nilsson, A. E., Taylor, J. J., \& Raito, K. (2019). Evidence of the impacts of metal mining and the effectiveness of mining mitigation measures on socialecological systems in Arctic and boreal regions: a systematic map protocol. Environ. Evid. 8(1): 1-11. https://doi.org/10.1186/s13750-019-0152-8.

Hakanson, L. (1980). An ecological risk index for aquatic pollution control. A sedimentological approach. Water Res. 14(8): 975-1001. https://doi.org/10.1016/0043-1354(80)90143-8.

Haris, H., Looi, L. J., Aris, A. Z., Mokhtar, N. F., Ayob, N. A. A., Yusoff, F. M., ... \& Praveena, S. M. (2017). Geoaccumulation index and contamination factors of heavy metals ( $\mathrm{Zn}$ and $\mathrm{Pb})$ in urban river sediment Envirnn Fenchem Health 39(h) - 1259-1271 https://doi.org/10.1007/s10653-017-9971-0. Loading [MathJax]/jax/output/CommonHTML/fonts/TeX/fontdata.js 
Hu, W., Wang, H., Dong, L., Huang, B., Borggaard, O. K., Hansen, H. C. B., ... \& Holm, P. E. (2018). Source identification of heavy metals in peri-urban agricultural soils of southeast China: an integrated approach. Environ. Pollut. 237: 650-661. https://doi.org/10.1016/j.envpol.2018.02.070.

Huang, X. X., Zhu, X. F., Tang, L., \& Ji, H. (2012). Pollution characteristics and their comparative study of heavy metals in the gold and iron mine soil of the upstream area of Miyun Reservoir, Beijing. Acta Scientiae Circumstantiae 32(6): 1520-1528.

Kara, C., \& Doratli, N. (2012). Application of GIS/AHP in siting sanitary landfill: a case study in Northern Cyprus. Waste Manag. Res. 30(9): 966-980. https://doi.org/10.1177/0734242X12453975.

Keshavarzi, A., \& Kumar, V. (2019). Ecological risk assessment and source apportionment of heavy metal contamination in agricultural soils of Northeastern Iran. Int. j. Environ. Health Res. 29(5): 544560. https://doi.org/10.1080/09603123.2018.1555638.

Kormoker, T., Proshad, R., Islam, S., Ahmed, S., Chandra, K., Uddin, M., \& Rahman, M. (2019). Toxic metals in agricultural soils near the industrial areas of Bangladesh: ecological and human health risk assessment. Toxin Rev.1-20. https://doi.org/10.1080/15569543.2019.1650777.

Kusin, F. M., Awang, N. H. C., Hasan, S. N. M. S., Rahim, H. A. A., Azmin, N., Jusop, S., \& Kim, K. W. (2019). Geo-ecological evaluation of mineral, major and trace elemental composition in waste rocks, soils and sediments of a gold mining area and potential associated risks. Catena 183:

104229. https://doi.org/10.1016/j.catena.2019.104229.

Langella, F., Grawunder, A., Stark, R., Weist, A., Merten, D., Haferburg, G., ... \& Kothe, E. (2014). Microbially assisted phytoremediation approaches for two multi-element contaminated sites. Environ. Sci. Pollut. Res. 21(11): 6845-6858. https://doi.org/10.1007/s11356-013-2165-0.

Laniyan, T. A., \& Adewumi, A. J. (2019). Health risk assessment of heavy metal pollution in groundwater around an exposed dumpsite in southwestern Nigeria. J. Health Pollut.

9(24). https://doi.org/10.5696/2156-9614-9.24.191210.

Laniyan, T. A., \& Adewumi, A. J. (2020). Potential ecological and health risks of toxic metals associated with artisanal mining contamination in ljero, southwest Nigeria. J. Environ. Sci. Health Part A, 55(7): 858877. https://doi.org/10.1080/10934529.2020.1751504.

Lee, J., Park, K. Y., Cho, J., \& Kim, J. Y. (2018). Releasing characteristics and fate of heavy metals from phytoremediation crop residues during anaerobic digestion. Chemosphere 191: 520-

526. https://doi.org/10.1016/j.chemosphere.2017.10.072.

Li, Q., Ji, H., Qin, F., Tang, L., Guo, X., \& Feng, J. (2014). Sources and the distribution of heavy metals in the particle size of soil polluted by gold mining upstream of Miyun Reservoir, Beijing: implications for 
assessing the potential risks. Environ. Monit. Assess. 186(10): 6605-6626.

https://doi.org/10.1007/s10661-014-3877-4.

Lilic, N., Cvjetic, A., Knezevic, D., Milisavljevic, V., \& Pantelic, U. (2018). Dust and noise environmental impact assessment and control in Serbian mining practice. Minerals 8(2):

34. https://doi.org/10.3390/min8020034.

Maanan, M., Saddik, M., Maanan, M., Chaibi, M., Assobhei, O., \& Zourarah, B. (2015). Environmental and ecological risk assessment of heavy metals in sediments of Nador lagoon, Morocco. Ecol. Indic. 48: 616626. https://doi.org/10.1016/j.ecolind.2014.09.034.

Mushtaha, A. L. İ., Elhagwa, A., Elfaki, J., \& Sulieman, M. (2017). Influence of the artisanal gold mining on soil contamination with heavy metals: A case study from Dar-Mali locality, North of Atbara, River Nile State, Sudan. Eurasian J. Soil Sci. 6(1): 28-36. https://doi.org/10.18393/ejss.284261.

Nirola, R., Megharaj, M., Palanisami, T., Aryal, R., Venkateswarlu, K., \& Naidu, R. (2015). Evaluation of metal uptake factors of native trees colonizing an abandoned copper mine-a quest for phytostabilization. J. Sustain.Min. 14(3): 115-123. https://doi.org/10.1016/j.jsm.2015.11.001.

Novo, L. A., \& González, L. (2014). Germination and early growth of Brassica juncea in copper mine tailings amended with technosol and compost. Sci. World J.

2014. https://doi.org/10.1155/2014/506392.

Okang'Odumo, B., Carbonell, G., Angeyo, H. K., Patel, J. P., Torrijos, M., \& Martín, J. A. R. (2014). Impact of gold mining associated with mercury contamination in soil, biota sediments and tailings in Kenya. Environ. Sci. Pollut. Res. 21(21): 12426-12435. https://doi.org/10.1007/s11356-014-3190-3.

Proshad, R., Kormoker, T., Islam, M. S., \& Chandra, K. (2020). Potential health risk of heavy metals via consumption of rice and vegetables grown in the industrial areas of Bangladesh. Hum. Ecol. risk Assess. Int. J. 26(4): 921-943. https://doi.org/10.1080/10807039.2018.1546114.

Siddiqui, E., \& Pandey, J. (2019). Assessment of heavy metal pollution in water and surface sediment and evaluation of ecological risks associated with sediment contamination in the Ganga River: a basin-scale study. Environ. Sci. Pollut. Res. 26(11): 10926-10940. https://doi.org/10.1007/s11356-019-04495-6.

Sulaiman, M. B., Salawu, K., \& Barambu, A. U. (2019). Assessment of concentrations and ecological risk of heavy metals at resident and remediated soils of uncontrolled mining site at Dareta Village, Zamfara, Nigeria. J. Appl. Sci. Environ. Manag. 23(1): 187-193. https://doi.org/10.4314/jasem.v23i1.28.

Sun, Y., Zhou, Q., Xie, X., \& Liu, R. (2010). Spatial, sources and risk assessment of heavy metal contamination of urban soils in typical regions of Shenyang, China. J. Hazard. Mater. 174(1-3): 455462. https://doi.org/10.1016/j.jhazmat.2009.09.074. 
Sundaray, S. K., Nayak, B. B., Lin, S., \& Bhatta, D. (2011). Geochemical speciation and risk assessment of heavy metals in the river estuarine sediments-a case study: Mahanadi basin, India. J. Hazard. Mater. 186(2-3): 1837-1846. https://doi.org/10.1016/j.jhazmat.2010.12.081.

Tytła, M., \& Kostecki, M. (2019). Ecological risk assessment of metals and metalloid in bottom sediments of water reservoir located in the key anthropogenic "hot spot" area (Poland). Environ. Earth Sci.78(5): 117. https://doi.org/10.1007/s12665-019-8146-y.

Wu, Y. G., Xu, Y. N., Zhang, J. H., \& Hu, S. H. (2010). Evaluation of ecological risk and primary empirical research on heavy metals in polluted soil over Xiaoqinling gold mining region, Shaanxi, China.

Transactions nonferrous met. Soc. China 20(4): 688-694. https://doi.org/10.1016/S1003-6326(09)601990 .

Zand, A. D., Darabi, H., Ghafouri, L., \& Talari, A. (2019). TRACE ELEMENTS EXTRACTION FROM METAL CONTAMINATED SOILS-IMPLICATION FOR RECLAMATION OF GOLD MINE AREAS. Environ. Eng. Manag. J. (EEMJ), 18(9).

Zhai, Y., Liu, X., Chen, H., Xu, B., Zhu, L., Li, C., \& Zeng, G. (2014). Source identification and potential ecological risk assessment of heavy metals in PM2. 5 from Changsha. Sci. Total.

Environ. 493: 109-115. https://doi.org/10.1016/j.scitotenv.2014.05.106.

Zhu, H. N., Yuan, X. Z., Zeng, G. M., Jiang, M., Liang, J., Zhang, C., ... \& Jiang, H. W. (2012). Ecological risk assessment of heavy metals in sediments of Xiawan Port based on modified potential ecological risk index. Transactions Nonferrous Met. Soc. China 22(6): 1470-1477. https://doi.org/10.1016/S10036326(11)61343-5.

\section{Figures}




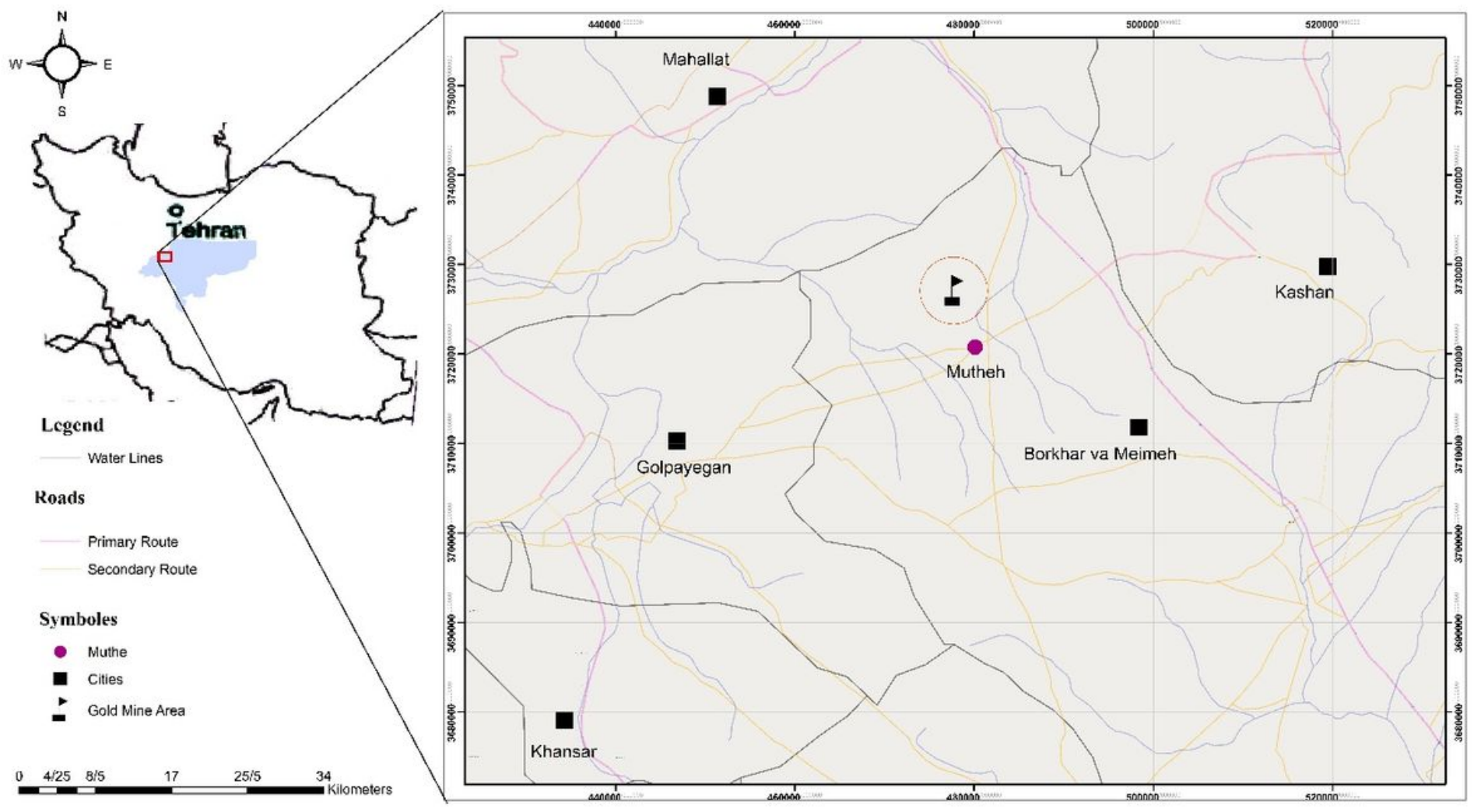

\section{Figure 1}

Muthe Gold Mine Location 


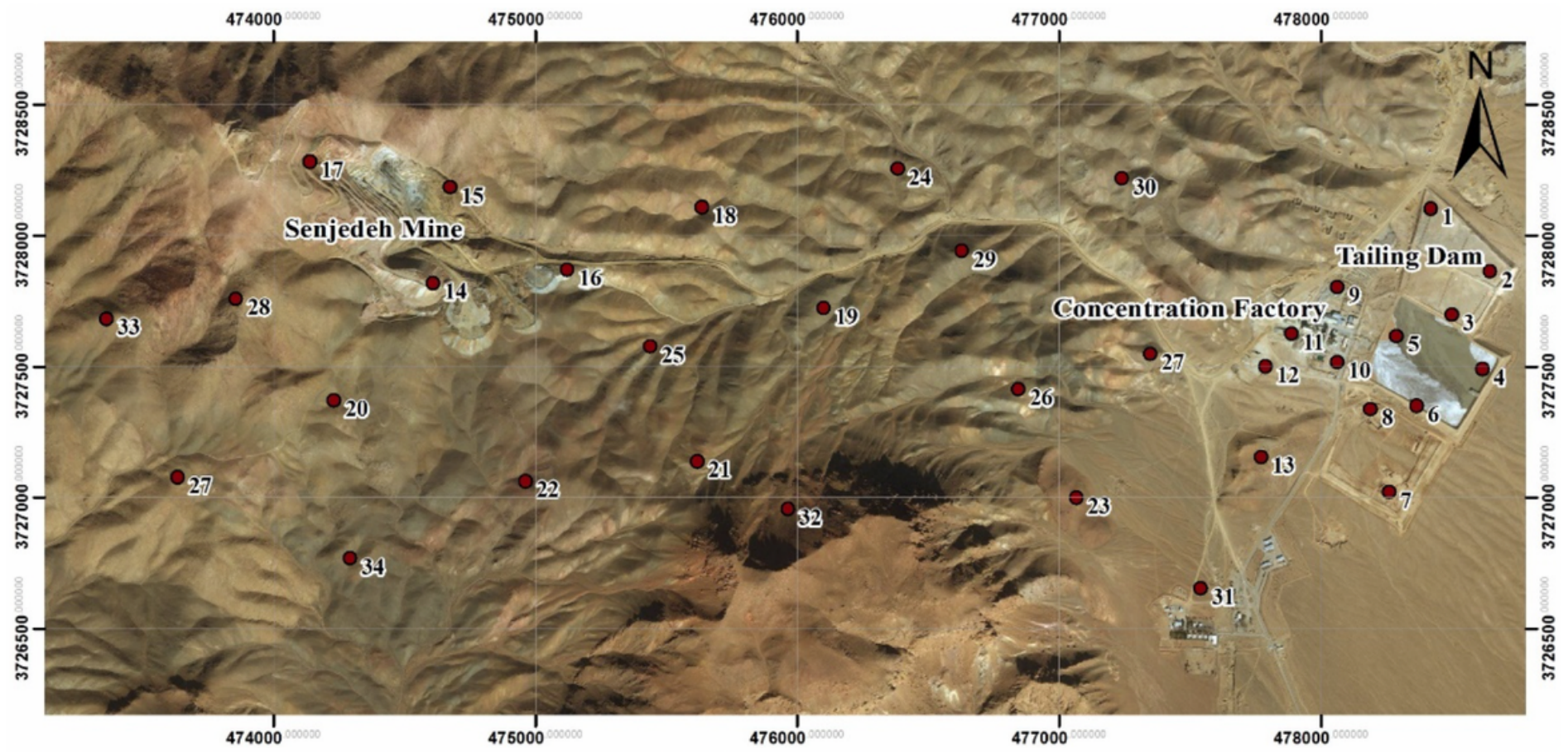

Figure 2

Sampling points (Satellite map: Arc Bru Tile 2017)
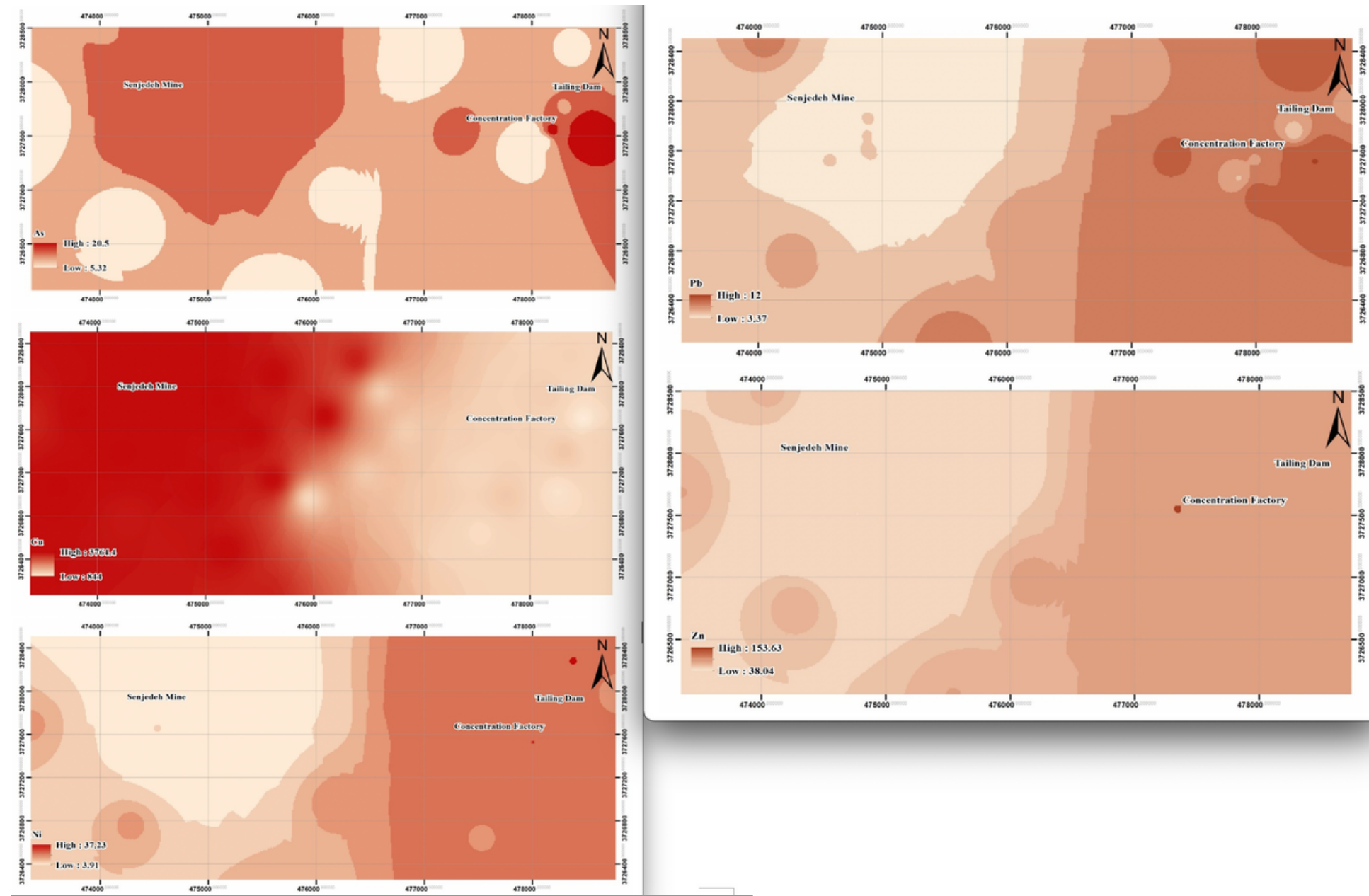

Loading [MathJax]/jax/output/CommonHTML/fonts/TeX/fontdata.js 
Figure 3

Interpolation mapping of heavy metals in Muthe gold mine area

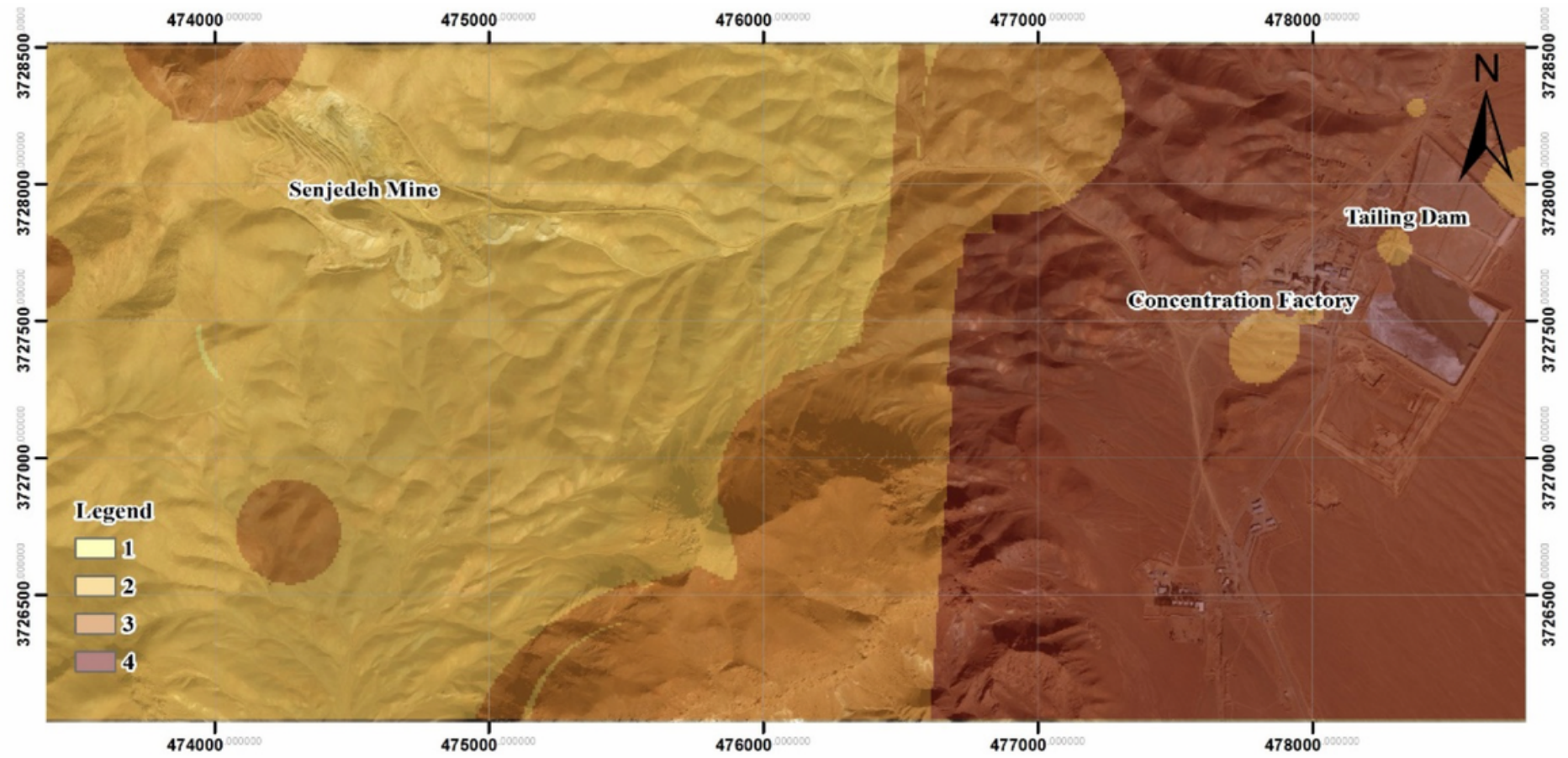

\section{Figure 4}

Weighted overlay mapping of trace elements 


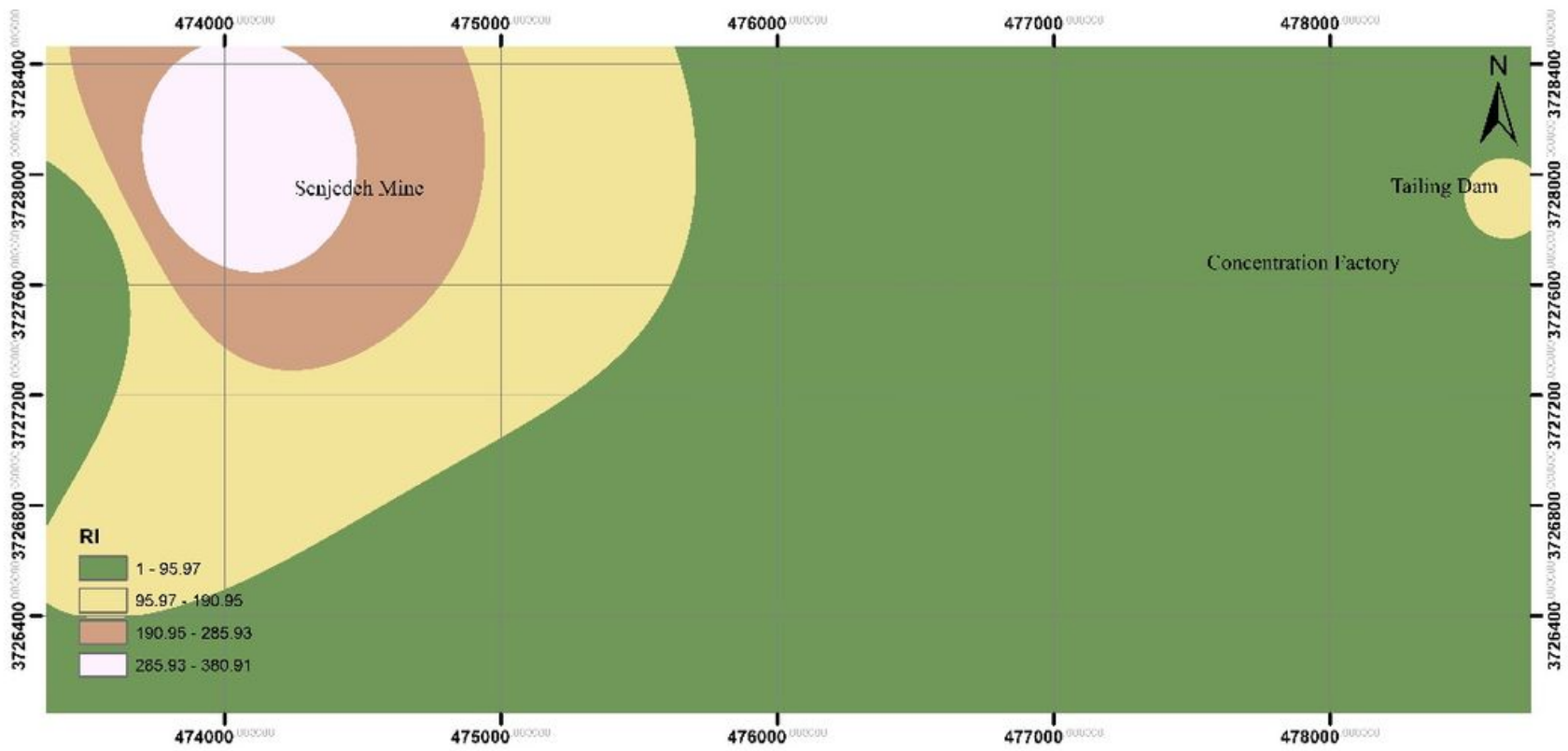

Figure 5

Ecological Risk Index Map 